\title{
Occurrence of a novel yeast enzyme, L-Lysine $\varepsilon$-dehydrogenase, which catalyses the first step of lysine catabolism in Candida albicans
}

\author{
ThOmas Hammer, RÜDIGer Bode* and Dieter Birnbaum \\ Institut für Biochemie, Fachrichtung Biologie, Ernst-Moritz-Arndt-Universität Greifswald, 2200 Greifswald, Germany
}

(Received 11 July 1990; revised 22 October 1990; accepted 9 November 1990)

\begin{abstract}
The yeast Candida albicans is able to utilize $\mathrm{L}$-lysine as the sole nitrogen and carbon source accompanied by intracellular accumulation of $\alpha$-aminoadipate- $\delta$-semialdehyde. A novel yeast amino acid dehydrogenase catalysing the oxidative deamination of the $\varepsilon$-group of L-lysine was found in this yeast. The enzyme, L-lysine $\varepsilon$-dehydrogenase, is strongly induced in cells grown on L-lysine as the sole nitrogen source. The enzyme is specific for both L-lysine and NADP ${ }^{+}$. The $K_{\mathrm{m}}$ values were determined to be $0.87 \mathrm{mM}$ for L-lysine and $0.071 \mathrm{mM}$ for NADP ${ }^{+}$. An apparent $M_{\mathrm{r}}$ of 87000 was estimated by gel filtration. The enzyme has maximum activity at pH 9.5 and a temperature optimum of $32{ }^{\circ} \mathrm{C}$ under our assay conditions.
\end{abstract}

\section{Introduction}

Both the biosynthesis and the catabolism of L-lysine show considerable variation from one life form to another. This amino acid is biosynthesized via two mutually exclusive pathways and no fewer than eight distinct catabolic routes have been proposed for animals, fungi and bacteria. In yeasts, two enzymic steps to initiate lysine degradation have been described so far. In Rhodotorula glutinis (Kinzel et al., 1983) and Pichia guilliermondii (Schmidt et al., 1988a) the first step of lysine catabolism is the conversion of this amino acid to $\alpha$-aminoadipate- $\delta$-semialdehyde by L-lysine $\varepsilon$-aminotransferase. In Hansenula saturnus (Rothstein, 1965), Yarrowia lipolytica (Gaillardin et al., 1976) and Candida maltosa (Schmidt et al., 1988b), lysine is catabolized via acetylated intermediates.

We present here evidence for the occurrence of a third initial step of lysine catabolism in Candida albicans caused by a novel yeast amino acid dehydrogenase that catalyses the oxidative deamination of the $\varepsilon$-amino group of L-lysine.

\section{Methods}

Strain and growth conditions. C. albicans SBUG 182 is a strain from our laboratory and was grown in minimal salt medium (Tanaka et al., 1967) supplemented with biotin $\left(1 \mathrm{mg} \mathrm{l}^{-1}\right)$ and thiamin $\left(1 \mathrm{mg} \mathrm{l}^{-1}\right)$, at $30^{\circ} \mathrm{C}$ on a rotary shaker $(100 \mathrm{ml}$ medium in $500 \mathrm{ml}$ flasks, 100 r.p.m.).

Enzyme preparation. Cells were harvested and subsequently washed with distilled water. The washed cells were resuspended in $100 \mathrm{mM}$ -
Tris/ $\mathrm{HCl}$ buffer ( $\mathrm{pH} \mathrm{9.5)} \mathrm{and} \mathrm{disrupted} \mathrm{by} \mathrm{passing} \mathrm{them} \mathrm{twice} \mathrm{through}$ an X-pressure cell $(110 \mathrm{MPa})$. Crude extract was obtained after removal of cell debris by centrifugation at $20000 \mathrm{~g}$ for $20 \mathrm{~min}$. To purify the enzyme, the broken yeast cells were resuspended in $100 \mathrm{~mm}-$ Tris/ $\mathrm{HCl}$ buffer ( $\mathrm{pH} \mathrm{9.5)} \mathrm{containing} 1 \mathrm{mM}$-dithioerythritol, $10 \mathrm{mM}-\mathrm{L}$ lysine and $2.25 \mathrm{M}$-ammonium sulphate, and the homogenate was centrifuged. The supernatant was chromatographed on a Sephadex G200 column $(1.6 \times 50 \mathrm{~cm})$, equilibrated and eluted with the same buffer. Fractions of $0.7 \mathrm{ml}$ were collected at a flow rate of $15 \mathrm{ml} \mathrm{h}^{-1}$. The pooled enzyme fractions were used to determine some properties of the enzyme. The L-lysine $\varepsilon$-dehydrogenase was purified sevenfold from the original extract with a recovery of $80 \%$. Under standard conditions the enzyme expressed a specific activity of 1.4 nkat (mg protein) ${ }^{-1}$.

Enzyme assay. The dehydrogenase activity was determined at $30^{\circ} \mathrm{C}$ by measuring the rate of increase in the absorbance at $340 \mathrm{~nm}$. The standard reaction mixture consisted of $10 \mathrm{~mm}-\mathrm{L}-\mathrm{lysine}, 1 \mathrm{~mm}-\mathrm{NADP}^{+}$, $100 \mathrm{~mm}-\mathrm{Tris} / \mathrm{HCl}$ buffer $(\mathrm{pH} \mathrm{9.5)}$ and enzyme solution in a final volume of $1.0 \mathrm{ml}$.

L-lysine aminotransferase and L-lysine acetyltransferase activity were determined according to Schmidt et al. $(1988 a, b)$.

Protein concentration in enzyme extracts was determined by the Lowry method using bovine serum albumin as standard.

Lysine and $\alpha$-aminoadipate- $\delta$-semialdehyde determination. Lysine concentration in the medium was determined according to a previously described method (Vogel \& Shimura, 1971), while $\alpha$-aminoadipate- $\delta$ semialdehyde was determined according to Sagisaka \& Shimura (1962).

\section{Results}

C. albicans SBUG 182 was tested for its ability to utilize L-lysine as a sole source of carbon or nitrogen. Results of growth experiments demonstrated that the yeast can use L-lysine in both ways. At the same molar nitrogen 
concentration of L-lysine and ammonium ( $5 \mathrm{~mm}$ ) no significant difference between the growth rates was observed $\left(\mu=0.32 \mathrm{~h}^{-1}\right)$ but at the same carbon concentration $(1 \%)$ the growth rate of the yeast with glucose was five times higher than with L-lysine as the sole carbon source. Similar to $R$. glutinis (Kinzel et al., 1983) and $P$. guilliermondii (Schmidt et al., 1988a), growth of $C$. albicans with lysine as the nitrogen source was accompanied by intracellular accumulation of $\alpha$-aminoadipate- $\delta$-semialdehyde $\left[0.4 \mathrm{mmol}(\mathrm{g} \text { dry wt })^{-1}\right]$. In the presence of lysine as the sole carbon source no semialdehyde accumulation was found.

On the basis of these findings we tested the activities of lysine aminotransferase and lysine acetyltransferase, two enzymes known to be involved in the first step of lysine catabolism in other yeasts, but neither of these could be detected. Only when L-lysine was incubated with the crude extract of $C$. albicans in the presence of $\mathrm{NADP}^{+}$or $\mathrm{NAD}^{+}$, was the synthesis of $\alpha$-aminoadipate$\delta$-semialdehyde observed. The reaction proceeded linearly as a function of the amount of enzyme and incubation time (Fig. 1). Both reaction products, NADPH and $\alpha$-aminoadipate- $\delta$-semialdehyde, were determined at the same concentration in the assay, indicating an $\varepsilon$-dehydrogenase reaction.

The dehydrogenase activity was normally present in only small amounts in $C$. albicans cells grown in minimal medium, but activity was much higher in extracts from cells grown in the presence of L-lysine (Table 1). In cells grown in medium containing L-lysine as the sole nitrogen source, the enzyme activity was increased more than 21 fold in comparison with that reached in cells grown in minimal medium. In the presence of cycloheximide no noticeable increase of the dehydrogenase activity was observed.

We followed the time course of both enzyme activity and lysine utilization of $C$. albicans cells grown with lysine as the sole nitrogen source. As shown in Fig. 2, the dehydrogenase activity strongly increased during growth and the maximum enzyme level was achieved between 12 and $20 \mathrm{~h}$ of growth; thereafter the enzyme activity decreased rapidly during further incubation.

To characterize the enzyme activity, cells were harvested after $16 \mathrm{~h}$ cultivation in medium containing Llysine as the sole nitrogen source and the crude extract was chromatographed on Sephadex G-200. The dehydrogenase activity was very sensitive to preparation procedures and could only be stabilized in the presence of ammonium sulphate, L-lysine and dithioerythritol. The enzyme eluted as one peak from the column and an $M_{\mathrm{r}}$ of $87000 \pm 5000$ was determined. Catalase, alcohol dehydrogenase, bovine serum albumin and ovalbumin served as calibration proteins.

The enzyme had its maximum activity around $\mathrm{pH} 9 \cdot 5$;

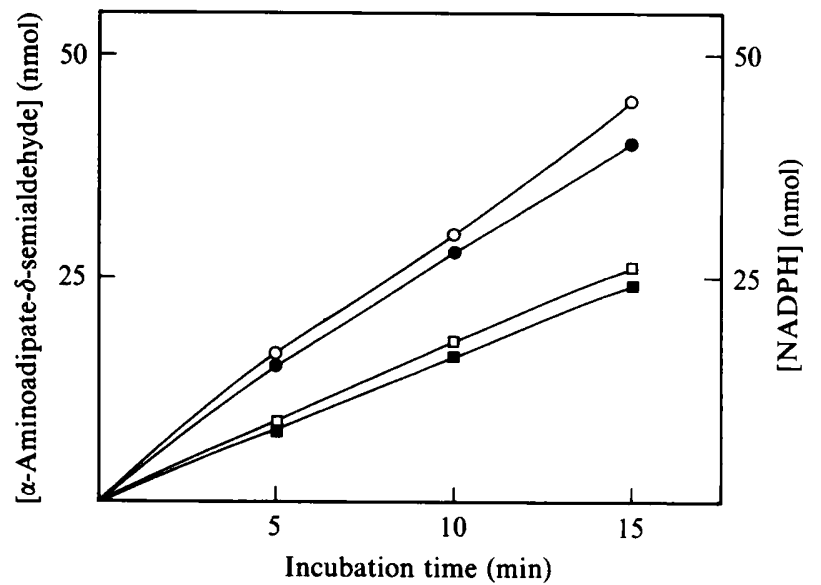

Fig. 1. Effect of incubation time on the activity of lysine $\varepsilon$ dehydrogenase in crude extract of cells grown in medium with ammonium as the sole nitrogen source. Both $\alpha$-aminoadipate- $\delta$ semialdehyde (filled symbols) and NADPH concentration (open symbols) were measured in the presence of $2.8 \mathrm{mg}$ protein $(\square, \square)$ and $5.6 \mathrm{mg}$ protein $(\mathrm{O}, 0)$ in the assay.

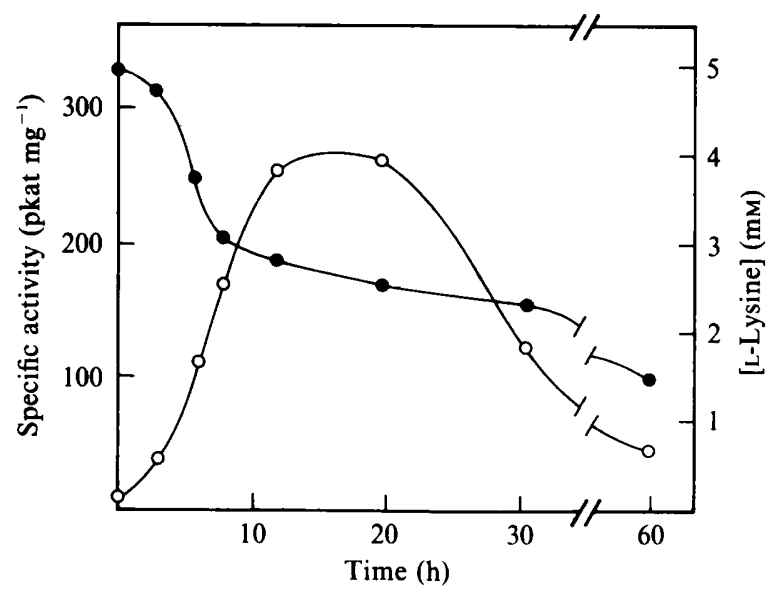

Fig. 2. Time course of lysine $\varepsilon$-dehydrogenase activity (O) from $C$. albicans and lysine concentration in the medium (๑). Cells were first grown for $16 \mathrm{~h}$ in minimal medium with $40 \mathrm{~mm}$-ammonium as the sole nitrogen source, then transferred to medium with $5 \mathrm{mM}-\mathrm{L}$-lysine as the sole nitrogen source and incubated at $30^{\circ} \mathrm{C}$.

$50 \%$ of the maximum activity was achieved at $\mathrm{pH} 7 \cdot 0$ and $11 \cdot 5$.

The dehydrogenase reaction was carried out at various temperatures in the standard reaction system. The reaction velocity increased linearly with temperature from 15 to $28{ }^{\circ} \mathrm{C}$. Maximum activity was found at $32{ }^{\circ} \mathrm{C}$ and the activation energy calculated from Arrhenius plots was $22 \cdot 1 \mathrm{~kJ} \mathrm{~mol}^{-1}$.

The amino acid specificity of the enzyme was studied using the standard assay system, in which the com- 
Table 1. Level of lysine $\varepsilon$-dehydrogenase in C. albicans incubated for $9 \mathrm{~h}$ in minimal medium of different composition

\begin{tabular}{|c|c|c|c|}
\hline $\begin{array}{c}\text { Carbon source } \\
(1 \%, w / v)\end{array}$ & Nitrogen source & Supplement & $\begin{array}{c}\text { Enzyme activity* } \\
\text { (pkat } \mathrm{mg}^{-1} \text { ) }\end{array}$ \\
\hline Glucose & $40 \mathrm{~mm}$-Ammonium & - & 10 \\
\hline Glucose & $40 \mathrm{~mm}$-Ammonium & $1 \mathrm{mM-L}-\mathrm{L} y s i n e$ & 18 \\
\hline Glucose & $40 \mathrm{~mm}$-Ammonium & 5 mM-L-Lysine & 48 \\
\hline Glucose & $40 \mathrm{~mm}$-Ammonium & $10 \mathrm{mM}$-L-Lysine & 65 \\
\hline Glucose & 5 mM-L-Lysine & - & 215 \\
\hline Glucose & 5 mM-L-Lysine & $0.1 \mathrm{~mm}$-Cycloheximide & 14 \\
\hline L-Lysine & $40 \mathrm{~mm}$-Ammonium & - & 79 \\
\hline Glucose & 5 mM-L-Leucine & - & 12 \\
\hline Glucose & 5 mM-L-Ornithine & - & 14 \\
\hline
\end{tabular}

* Crude extract was used.

Table 2. Substrate specificity of lysine $\varepsilon$-dehydrogenase

\begin{tabular}{|c|c|c|c|c|}
\hline \multirow[b]{3}{*}{ Substrate* $(10 \mathrm{~mm})$} & \multicolumn{4}{|c|}{ Relative activity $(\%)$} \\
\hline & \multicolumn{2}{|c|}{ Uninduced cells } & \multicolumn{2}{|c|}{ Induced cells } \\
\hline & $\begin{array}{l}\text { Crude } \\
\text { extract }\end{array}$ & $\begin{array}{c}\text { Gel } \\
\text { filtration } \\
\text { eluate }\end{array}$ & $\begin{array}{l}\text { Crude } \\
\text { extract }\end{array}$ & $\begin{array}{c}\text { Gel } \\
\text { filtration } \\
\text { eluate }\end{array}$ \\
\hline L-Lysine & 100 & 100 & 100 & 100 \\
\hline D-Lysine & 0 & 0 & 0 & 0 \\
\hline$S$-( $\beta$-Aminoethyl $)$-L-cysteine & 66 & 48 & 65 & 42 \\
\hline$\delta$-Hydroxylysine & 38 & 25 & 40 & 21 \\
\hline L-Leucine & 20 & 20 & 20 & 21 \\
\hline L-Isoleucine & 5 & 4 & 10 & 5 \\
\hline L-Ornithine & 9 & 10 & 12 & 14 \\
\hline
\end{tabular}

* None of the following amino acids could be used as substrate: L-histidine, $L-\alpha-$ aminoadipate, $\beta$-alanine, L-alanine, L-arginine, L-valine, L-phenylalanine, L-tryptophan, L-tyrosine, L-glutamate, L-aspartate, L-proline, L-serine, L-threonine, L-methionine. Only the gel filtration eluate was used.

$\dagger$ The specific activities were: $10 \mathrm{pkat} \mathrm{mg}^{-1}$ (uninduced cells, crude extract), $55 \mathrm{pkat} \mathrm{mg}^{-1}$ (uninduced cells, gel filtration eluate), 205 pkat $\mathrm{mg}^{-1}$ (induced cells, crude extract),

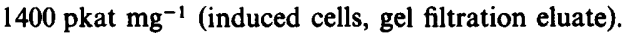

pounds in question were substituted for L-lysine, usually at the same concentration $(10 \mathrm{~mm})$. Table 2 shows the specificity of the enzyme obtained from induced and uninduced cells, both before and after gel filtration. The highest activity was obtained with L-lysine. The enzyme was also able to convert lysine derivatives $[S-(\beta-$ aminoethyl)-L-cysteine, $\delta$-hydroxylysine] and L-leucine or L-ornithine, but to a lesser extent.

The enzyme required $\mathrm{NADP}^{+}$as a natural coenzyme for the oxidative deamination of L-lysine. $\mathrm{NAD}^{+}$could also serve as coenzyme, but the enzyme activity in the presence of $1 \mathrm{mM}-\mathrm{NAD}^{+}$was only a third of the activity with $1 \mathrm{mM}-\mathrm{NADP}^{+}$.
Apparent $K_{\mathrm{m}}$ values for L-lysine and $\mathrm{NADP}^{+}$were determined either by varying concentrations of $L$-lysine at a fixed concentration of $\mathrm{NADP}^{+}$or by varying concentrations of $\mathrm{NADP}^{+}$at a fixed concentration of $\mathrm{L}^{-}$ lysine. The double reciprocal plots were linear, indicating normal Michaelis-Menten kinetics, and the $K_{\mathrm{m}}$ values for $\mathrm{L}^{-l y s i n e}$ and $\mathrm{NADP}^{+}$were determined to be $0.87 \mathrm{mM}$ and $0.071 \mathrm{mM}$, respectively (not shown).

The effect of different potential effectors on the enzyme activity was tested. As shown in Table 3, the enzyme was inhibited completely by $p$-chloromercuribenzoate and $\mathrm{HgCl}_{2}$. Some divalent metal ions also decreased the activity, but to a lesser extent. 
Table 3. Influence of potential effectors on activity of lysine $\varepsilon$-dehydrogenase

\begin{tabular}{lc}
\hline \hline $\begin{array}{c}\text { Effector } \\
(1 \mathrm{mM})\end{array}$ & $\begin{array}{c}\text { Relative activity* } \\
(\%)\end{array}$ \\
\hline None & 100 \\
$\mathrm{CaCl}_{2}$ & 89 \\
$p$-Chloromercuribenzoate & 0 \\
$\mathrm{CoCl}_{2}$ & 33 \\
$\mathrm{CuCl}_{2}$ & 24 \\
$\mathrm{EDTA}$ & 93 \\
$\mathrm{FeCl}_{2}$ & 100 \\
$\mathrm{HgCl}_{2}$ & 0 \\
$\mathrm{KCN}_{\mathrm{MgCl}_{2}}$ & 95 \\
$\mathrm{MnCl}_{2}$ & 100 \\
$\mathrm{NaN}_{3}$ & 29 \\
$\mathrm{SnCl}_{2}$ & 78 \\
\hline${ }^{2}$ & 100 \\
\hline
\end{tabular}

- Gel filtration eluate was used.

\section{Discussion}

The results reported in this study show that $C$. albicans is capable of catabolizing L-lysine as the sole nitrogen and carbon source by a novel dehydrogenase that converts Llysine to $\alpha$-aminoadipate- $\delta$-semialdehyde. This compound is probably converted to $\alpha$-aminoadipate, 2 oxoadipate and glutarate via a pathway similar to that of Pseudomonas aeruginosa (Fothergill \& Guest, 1977). The high derepression of the L-lysine $\varepsilon$-dehydrogenase activity from yeast cells grown in lysine-containing medium indicates that the enzyme plays an important role in the catabolism of lysine in C. albicans. The levels of enzyme derepression in cells grown with lysine as the sole nitrogen source and in cells grown with lysine as the sole carbon source were different and corresponded with the yeast growth rate in the media. In addition, the absence of any other enzyme activities of lysine degradation suggests that this dehydrogenase reaction represents the first step in degradation of L-lysine in this yeast. A significant derepression by lysine of lysine aminotransferase and lysine acetyltransferase, the first enzymes of lysine degradation in $R$. glutinis, $P$. guilliermondii and $C$. maltosa, respectively, was also observed (Kinzel et al., 1983; Schmidt et al., 1988a, b).

L-Lysine $\varepsilon$-dehydrogenase has not been demonstrated in any eukaryote, but the enzyme activity was found in some bacteria (Misono \& Nagasaki, 1983). The highest activity was obtained in Agrobacterium tumefaciens. The enzyme from this organism was purified and characterized in detail (Misono \& Nagasaki, 1982; Misono et al., 1989). In contrast to the enzyme from $C$. albicans, the $A$. tumefaciens enzyme was specific for $\mathrm{NAD}^{+}$and did not react with NADP+ ${ }^{+}$In addition to L-lysine, only $S$ - $(\beta$ aminoethyl)-L-cysteine showed reactivity $(2.9 \%)$ with the $A$. tumefaciens enzyme. The dehydrogenase from $C$. albicans is able to deaminate lysine derivatives as well as ornithine and leucine. Since the enzyme was not purified to homogeneity, other dehydrogenase activities can not be excluded. The latter two amino acids, however, were unable to derepress the lysine $\varepsilon$-dehydrogenase activity (Table 1). Therefore, a physiological role of deamination of both ornithine and leucine by lysine $\varepsilon$-dehydrogenase is probably excluded.

The basic kinetic properties of the dehydrogenase obtained here (L-lysine $K_{\mathrm{m}} 0.87 \mathrm{mM} ; \mathrm{NADP}^{+} K_{\mathrm{m}}$ $0.071 \mathrm{mM}$ ) are comparable with those reported for the enzyme from $A$. tumefaciens (L-lysine $K_{\mathrm{m}} 1.5 \mathrm{mM}$; NAD ${ }^{+}$ $K_{\mathrm{m}} 0.06 \mathrm{mM}$ ). The $\mathrm{pH}$ optimum of the enzyme reaction and the behaviour of the enzyme from both sources with mercury-containing compounds are also similar. The $M_{\mathrm{r}}$ of the native enzyme from $C$. albicans was determined to be 87000 , which is somewhat different from that found for the Agrobacterium dehydrogenase (78000).

It is interesting to note that among 28 yeast species (17 genera), which were studied with respect to their enzyme recruitment, besides $C$. albicans only Kluyveromyces marxianus possessed lysine $\varepsilon$-dehydrogenase activity ( $\mathrm{T}$. Hammer, unpublished). This suggests that L-lysine $\varepsilon$ dehydrogenase is not widely distributed among yeasts.

\section{References}

Fothergill, J. C. \& Guest, J. R. (1977). Catabolism of L-lysine by Pseudomonas aeruginosa. Journal of General Microbiology 99, 139155.

Gaillardin, C., Fournier, P., Sylvestre, G. \& Heslot, H. (1976). Mutants of Saccharomycopsis lipolytica defective in lysine catabolism. Journal of Bacteriology 125, 48-57.

KinZeL, J. J., Winston, M. K. \& BHATtAChARJEE, J. K. (1983). Role of $\mathrm{L}$-lysine- $\alpha$-ketoglutarate aminotransferase in catabolism of lysine as a nitrogen source for Rhodotorula glutinis. Journal of Bacteriology 155, 417-419.

Misono, H. \& NAGASAKI, S. (1982). Occurrence of L-lysine $\varepsilon-$ dehydrogenase in Agrobacterium tumefaciens. Journal of Bacteriology 150, 398-401.

Misono, H. \& Nagasaki, S. (1983). Distribution and physiological function of L-lysine $\varepsilon$-dehydrogenase. Agricultural and Biological Chemistry 47, 631-633.

Misono, H., Hashimoto, H., Uehigashi, H., Nagata, S. \& Nagasaki, S. (1989). Properties of L-lysine $\varepsilon$-dehydrogenase from Agrobacterium tumefaciens. Journal of Biochemistry 105, 1002-1008.

RothsteIn, M. (1965). Intermediates of lysine dissimilation in the yeast, Hansenula saturnus. Archives of Biochemistry and Biophysics $111,467-476$.

SaGisaka, S. \& Shimura, K. (1962). Studies in lysine biosynthesis. III. Enzymic reduction of $\alpha$-aminoadipic acid: isolation and some properties of the enzyme. Journal of Biochemistry 51, 398-404.

Schmidt, H., Bode, R. \& Birnbaum, D. (1988a). A novel enzyme, Llysine:pyruvate aminotransferase, catalyses the first step of lysine catabolism in Pichia guilliermondii. FEMS Microbiology Letters 49, 203-206. 
SCHMidT, H., BoDE, R. \& Birnbaum, D. (1988b). Lysine degradation in Candida maltosa: occurrence of a novel enzyme, acetyl-CoA :L-lysine $N$-acetyltransferase. Archives of Microbiology 150, 215-218.

TANAKA, A., OHISHI, N. \& FuJuI, S. (1967). Studies on the formation of vitamins and their function in hydrocarbon fermentation. Produc- tion of vitamin $\mathbf{B}_{6}$ by Candida albicans in hydrocarbon medium. Journal of Fermentation Technology 45, 617-623.

VoGEL, H. J. \& SHIMURA, Y. (1971). Spectrophotometric determination of lysine. Methods in Enzymology 17B, 228-229. 